\title{
Analysis of input-output relationships of CPG elements and their contributions to rhythmic output
}

\author{
Terrence Michael Wright $\mathrm{Jr}^{1,2^{*}}$, Brian Mulloney ${ }^{2}$, Ronald L Calabrese \\ From Twenty First Annual Computational Neuroscience Meeting: CNS*2012 \\ Decatur, GA, USA. 21-26 July 2012
}

We use the dynamic clamp technique [1] to explore how synaptic input patterns affect motor output (see Figure 1A). We show that leech motor neuron intrinsic properties make a contribution to their output phasing. Then, we show that leech motor neurons receiving the same complement of synaptic inputs can still be organized into a coordinated motor pattern given that a gradient of synaptic strengths exists and that the premotor interneurons fire at different times [2]. In both of these cases, measuring motor neuron responses provides a direct assay for how premotor input patterns produce stereotyped motor output. We are currently extending this analysis to the crayfish swimmeret system, a system in which four segmental oscillators are interconnected by coordinating interneurons to produce a metachronal wave of swimmeret movements [3]. In this system, ascending (ASC) and descending (DSC) coordinating interneurons (see Figure 1B) encode salient features

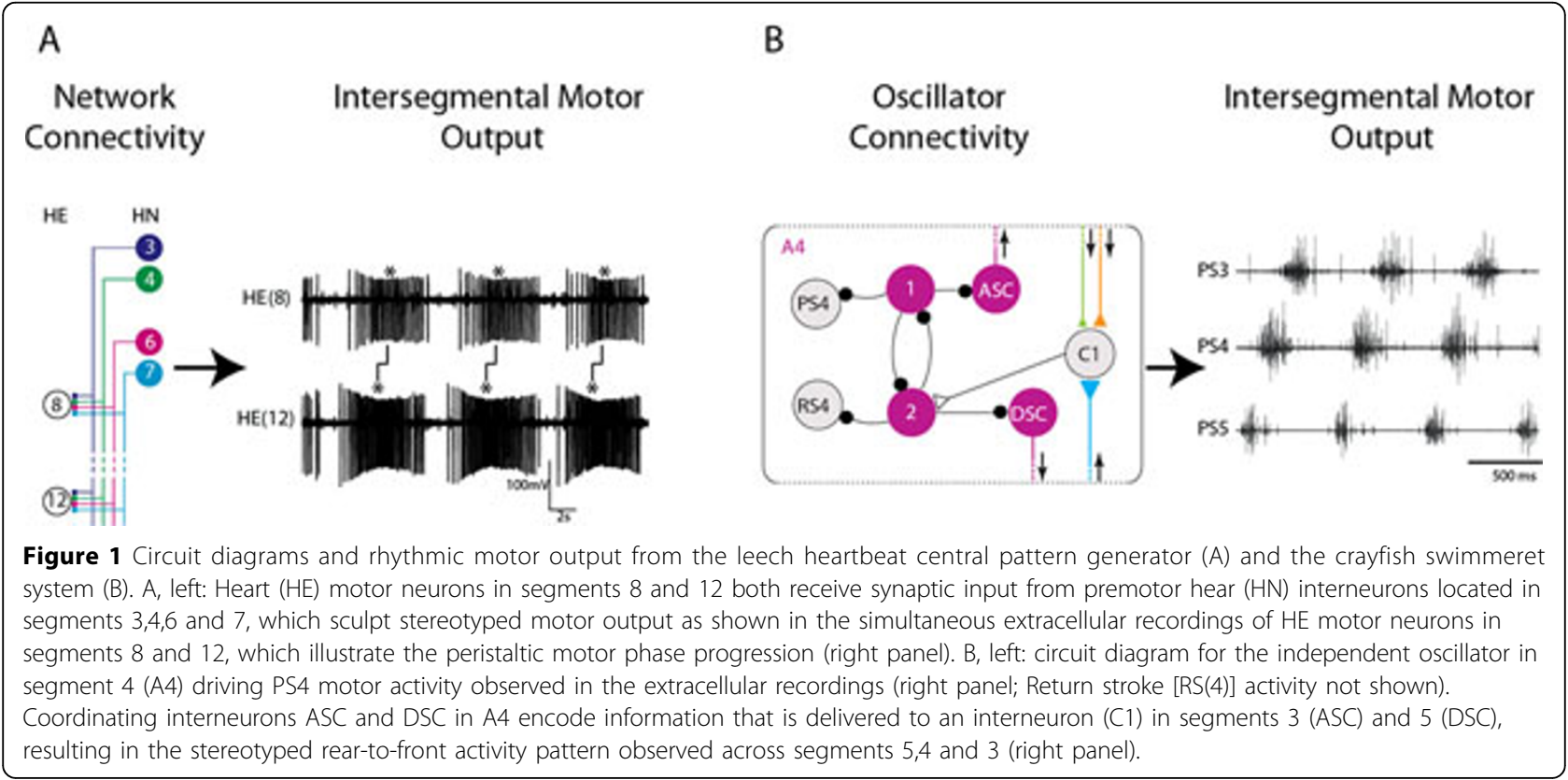

\footnotetext{
* Correspondence: terrencemwright@msn.com

'Department of Biology, Emory University, Atlanta, GA 30322, USA
}

Full list of author information is available at the end of the article 
about the activity pattern of their home segment and are exported (via spikes) to other segmental oscillators. Interestingly, when the system is driven across periods by different concentrations of neuromodulators, the number of spikes of a given coordinating interneuron remains constant although their duty cycles change. We are currently building a single-compartment, conductance-based model of the ASC and DSC coordinating neurons, with the goal of understanding how these coordinating neurons encode information in their home modules and how this encoding can be modulated when the swimmeret system is driven at different periods.

\section{Author details}

'Department of Biology, Emory University, Atlanta, GA 30322, USA.

${ }^{2}$ Department of Neurobiology, Physiology and Behavior, University of California, Davis, Davis, CA, 95616, CA, USA

Published: 16 July 2012

\section{References}

1. Sharp AA, O'neil MB, Abbott LF, Marder E: Dynamic clamp: artificial conductances in biological neurons. Trends Neurosci 1993, 16(10):389-94.

2. Wright TM, Calabrese RL: Patterns of presynaptic activity interact to produce motor output. J Neurosci 2011, 31(48):17555-71.

3. Smarandache-Wellmann C, Mulloney B: Neurobiology of the crayfish swimmeret system. Prog Neurobiol 2012, 96(2):242-67.

doi:10.1186/1471-2202-13-S1-P171

Cite this article as: Wright et al: Analysis of input-output relationships of CPG elements and their contributions to rhythmic output. BMC

Neuroscience 2012 13(Suppl 1):P171.

\section{Submit your next manuscript to BioMed Central} and take full advantage of:

- Convenient online submission

- Thorough peer review

- No space constraints or color figure charges

- Immediate publication on acceptance

- Inclusion in PubMed, CAS, Scopus and Google Scholar

- Research which is freely available for redistribution

Submit your manuscript at www.biomedcentral.com/submit 